\title{
UPAYA MENINGKATKAN HASIL BELAJAR IPS DENGAN MENGGUNAKAN STRATEGI PEMBELAJARAN INKUIRI (SPI)
}

\author{
Chandra Anugrah Putra \\ Nikita Dewi \\ Universitas MuhammadiyahPalangkaraya
}

\begin{abstract}
Abstrak: Penelitian ini bertujuan untuk : (1) mengetahui aktivitas belajar peserta didik selama mengikuti pembelajaran IPS melalui strategi pembelajaran inquiry (SPI) , (2) mengetahui peningkatan hasil belajar peserta didik dalam pembelajaran IPS setelah belajar melalui strategi pembelajaran inquiry (SPI). Penelitian ini dilakukan pada minggu ke-3 dan ke-4 bulan Mei 2015 yang berlokasi di SDN 2 Mambulau, Kecamatan Kapuas Hilir. Jenis penelitian ini adalah Penelitian Tindakan Kelas ( PTK ) dengan subjek penelitian seluruh peserta didik kelas IV SDN 2 Mambulau yang berjumlah 7 orang. Teknik pengumpulan data dalam penelitian ini menggunakan tes dan observasi. Analisis data menggunakan analisis data kualitatif dan kuantitatif. Indikator keberhasilan dalam penelitian ini adalah apabila ketuntasan aktivitas belajar peserta didik secara klasikal mencapai skor minimal 3, hasil belajar dengan kriteria ketuntasan minimal 60 dengan ketuntasan belajar secara klasikal mencapai nilai minimal 85\%. Hasil penelitian ini menunjukkan bahwa : (1) penggunaan strategi pembelajaran inquiry (SPI) pada mata pelajaran IPS lebih aktif peserta didik yang ditunjukkan dengan perolehan skor hasil pengamatan di atas 3, (2) pengunaan strategi pembelajaran inquiry pada mata pelajaran IPS dapat meningkatkan hasil belajar peserta didik yang ditunjukkan dengan perolehan nilai rata-rata 62,85 pada siklus I meningkat menjadi 76,42 pada siklus II. Ketuntasan belajar secara klasikal juga mengalami peningkatan dengan nilai $71 \%$ pada siklus I meningkat menjadi 85,7\% pada siklus II.
\end{abstract}

Kata Kunci: Hasil Belajar, IPS, Strategi Pembelajaran, Inkuiri.

\section{PENDAHULUAN}

Dalam dunia pendidikan terutama dalam kegiatan pembelajaran, memiliki komponen pembelajaran yang meliputi aspek tujuan pembelajaran, siswa, guru, materi pelajaran, metode pembelajaran, media pembelajaran dan evaluasi pembelajaran. Di lapangan, banyak ditemukan berbagai permasalahan dalam pembelajaran, salah satunya yaitu anak kesulitan memahami materi yang diajarkan. Salah satu faktor yang menyebabkan hal itu antara lain strategi pembelajaran yang digunakan oleh guru kurang inovatif sehingga siswa kurang tertarik dan cenderung pasif dalam kegiatan pembelajarannya. Oleh karena itu, seorang guru harus mendesain kegiatan pembelajarannya agar menjadi pembelajaran yang kondusif.

Berdasarkan Standar Kompetensi dan Kompetensi Dasar Tingkat SD/MI dalam Peraturan Menteri Pendidikan Nasional Nomor 22 Tahun 2006 tentang Standar Isi untuk satuan pendidikan dasar dan menengah bahwa standar kompetensi IPS adalah ilmu yang mengkaji seperangkat peristiwa, fakta, konsep, dan generalisasi yang berkaitan dengan isu sosial. Dengan kompetensi tersebut maka peserta didik diarahkan untuk dapat menjadi warga negara Indonesia yang demokratis, dan bertanggung jawab, serta warga dunia yang cinta damai. Serta mata pelajaran IPS dirancang untuk mengembangkan pengetahuan, pemahaman, dan kemampuan analisis 
terhadap kondisi sosial masyarakat dalam memasuki kehidupan bermasyarakat yang dinamis.

Tujuan mata pelajaran IPS adalah mengenal konsep-konsep yang berkaitan dengan kehidupan masyarakat dan lingkungannya. Memiliki kemampuan dasar untuk berpikir logis dan kritis, rasa ingin tahu, inkuiri, memecahkan masalah, dan keterampilan dalam kehidupan sosial. Memiliki komitmen dan kesadaran terhadap nilai-nilai sosial dan kemanusiaan. Memiliki kemampuan berkomunikasi, bekerjasama dan berkompetisi dalam masyarakat yang majemuk, di tingkat lokal, nasional, dan global. Mata pelajaran IPS pada satuan pendidikan SD/MI meliputi manusia, tempat, dan lingkungan, waktu, keberlanjutan, dan perubahan sistem sosial dan budaya, perilaku ekonomi dan kesejahteraan. Pemahaman pada materi pelajaran IPS sangat diperlukan sebab materi IPS merupakan materi yang luas dan abstrak.

Pembelajaran adalah suatu kombinasi yang tersusun meliputi unsurunsur manusiawi, material, fasilitas, perlengkapan dan prosedur yang saling mempengaruhi untuk mencapai tujuan pembelajaran (Oemar Hamalik, 1995:57). Dalam suatu pembelajaran menjadi suatu sistem yang tersusun atas beberapa komponen yang saling berkaitan satu sama lain. Interaksi antara guru dan siswa dalam pembelajaran menjadi hal yang sangat penting. Namun, pada saat ini banyak ditemukan siswa yang kesulitan memahami materi pelajaran IPS. Hal ini ditunjukkan dengan hasil belajar IPS yang masih rendah. Pembelajaran IPS saat ini belum bisa meningkatkan pemahaman siswa. Hal ini disebabkan oleh cara penyampaian materi dengan metode yang monoton dan tidak bervariasi serta minimnya alat peraga yang digunakan sehingga siswa kurang mampu memahami dan menguasai materi IPS yang abstrak tersebut.
Berdasarkan hasil observasi saya pada bulan januari tahun 2015 di SDN 2 MAMBULAU, kecamatan Kapuas Hilir saya mendapatkan fenomena pada kelas IV mengenai kurangnya minat belajar peserta didik dalam proses pembelajaran IPS. Karena, Guru dalam proses belajar mengajar cenderung menerapkan metode pembelajaran ceramah dan pemberian tugas sehingga membuat peserta didik kurang aktif dalam proses pembelajaran, dan dari wawancara peneliti kepada salah satu peserta didik dikelas IV mengungkapkan bahwa pelajaran IPS itu dianggap mereka membosankan .

Dari hasil evaluasi yang diberikan guru pun masih ada yang tidak dapat mencapai nilai KKM yang telah ditentukakan. Dari keseluruhan peserta didik dikelas IV yang berjumlah 7 orang, hanya $4(58 \%)$ peserta didik yang mampu mencapai kriteria ketuntasan minimum, sedangkan untuk $3(42 \%)$ peserta didik terdiri dari 2 orang laki-laki dan 1 orang perempuan yang nilai pelajaran IPS di bawah standar kriteria minimum ( KKM) yaitu 60 .

Melihat kenyataan tersebut maka peneliti tertarik untuk melakukan penelitian dengan judul “ Upaya Meningkatkan Hasil Belajar IPS dengan Menggunakan Strategi Pembelajaran Inkuiri (SPI) Kelas IV SDN 2 Mambulau Tahun Pelajaran 2014/2015.

Menurut R. Gagne (1989), belajar dapat didefinisikan sebagai suatu proses dimana suatu organisme berubah perilakunya sebagai akibat pengalaman. Belajar dan mengajar merupakan dua konsep yang tidak dapat dipisahkan satu sama lain. Dua konsep ini menjadi terpadu dalam satu kegiatan di mana terjadi interaksi antara guru dengan siswa, serta siswa dengan siswa pada saat pembelajaran berlangsung.

Adapun menurut Burton dalam Usman dan Setiawati (1993:4), belajar dapat diartikan sebagai perubahan tingkah laku pada diri individu berkat adanya interaksi antara individu dengan individu 
lain dan individu dengan lingkungannya sehingga mereka lebih mampu berinteraksi dengan lingkungannya.

Sementara menurut E.R. Hilgard (1962), belajar adalah suatu perubahan kegiatan reaksi terhadap lingkungan. Perubahan kegiatan yang dimaksud mencakup pengetahuan, kecakapan, tingkah laku, dan ini diperoleh melalui latihan (pengalaman). Hilgard menegaskan bahwa belajar merupakan proses mencari ilmu yang terjadi dalam diri seseorang melalui latihan, pembiasaan, pengalaman dan sebagainya.

Berdasarkan uraian tentang konsep belajar di atas, dapat dipahami tentang makna hasil belajar, yaitu perubahanperubahan yang terjadi pada diri siswa, baik yang menyangkut aspek kognitif, akfektif, dan psikimotor sebagai kegiatan belajar. Pengertian tentang hasil belajar sebagaimana diuraikan diatas dipertegas oleh Nawawi dalam K. Brahim (2007:39) yang menyatakan bahwa hasil belajar dapat diartikan sebagai tingkat keberhasilan siswa dalam mempelajari materi pelajaran di sekolah yang dinyatakan dalam skor yang diperoleh dari hasil tes mengenal sejumlah materi tertentu.

Secara sederhana, yang dimaksud dengan hasil belajar siswa adalah kemampuan yang diperoleh anak setelah melalui kegiatan belajar. Karena belajar itu sendiri merupakan suatu proses dari seseorang yang berusaha untuk memperoleh suatu bentuk perubahan perilaku yang relatif menetap. Untuk mengetahui apakah hasil belajar yang dicapai telah sesuai dengan tujuan yang dikehendaki dapat diketahui melalui evaluasi. Sebagaimana dikemukakan oleh Sunal (1993:94), bahwa evaluasi merupakan proses penggunaan informasi untuk membuat pertimbangan seberapa efektif suatu program telah memenuhi kebutuhan siswa.

Sedangkan Nana Sudjana (2009:3) mendefinisikan hasil belajar siswa pada hakikatnya adalah perubahan tingkah laku sebagai hasil belajar dalam pengertian yang lebih luas mencakup bidang kognitif, afektif, dan psikomotorik. Menurut Hamalik (2003:155) hasil belajar adalah sebagai terjadinya tingkah laku pada diri seseorang yang dapat diamati dan di ukur dalam bentuk pengetahuan, sikap, dan keterampilan. Perubahan tersebut dapat diartikan sebagai terjadinya peningkatan dan pengembangan yang lebih baik dari sebelumnya yang tidak tahu menjadi tahu. Dimyanti dan Mudjiono (2006:3-4) juga menyebutkan hasil belajar merupakan hasil dari suatu interaksi tindak belajar dan tindak mengajar. Dari sisi guru tindak mengajar diakhiri dengan proses evaluasi hasil belajar. Dari sisi siswa, hasil belajar merupakan berakhirnya pengajaran dari puncak proses belajar.

Berdasarkan pengertian hasil belajar di atas, disimpulkan bahwa hasil belajar adalah kemampuan-kemampuan yang dimiliki siswa setelah menerima pengalaman belajarnya. Kemampuankemampuan tersebut mencakup aspek kognitif, afektif, dan spikomotorik. Hasil belajar dapat dilihat melalui kegiatan evaluasi yang bertujuan untuk mendapatkan data pembuktian yang akan menunjukan tingkat kemampuan siswa dalam mencapai tujuan pembelajaran.

IPS merupakan bidang studi baru karena dikenal sejak diberlakukan kurikulum 1975. Dalam bidang Ilmu Pengetahuan Sosial terdapat beberapa istilah seperti Ilmu Sosial (social sciences), Studi Sosial (social studies), dan IPS. Ahmad Sanusi ( Hidayati, 2004:5) memberikan batasan tentang Ilmu Sosial sebagai berikut, "Ilmu sosial terdiri dari disiplin-disiplin ilmu pengetahuan sosial yang bertaraf akademis dan biasanya dipelajari pada tingkat perguruan tinggi yang makin lanjut dan makin ilmiah". Gross (Hidayati, 2004:5) juga mengemukan Ilmu Sosial merupakan disiplin intelektual yang mempelajari manusia sebagai makhluk sosial yang secara ilmiah memusatkan pada manusia 
sebagai anggota masyarakat dan kelompok atau masyarakat yang dibentuk.

Berbeda dengan Ilmu Sosial, Sumaatmadja (Rudy Gunawan, 2011:19) mengemukan bahwa, "Studi sosial bukan merupakan suatu bidang keilmuan atau disiplin akademis, 1melainkan lebih merupakan suatu bidang pengkajian tentang gejala dan masalah sosial". Rudy Gunawan (2011:36) mengemukakan bahwa IPS adalah suatu bahan kajian yang merupakan penyerderhanaan, adaptasi, seleksi dan modifikasi yang diorganisasiakn dari konsep-konsep dan keterampilan sejarah, geografi, sosiologi, antropologi, dan ekonomi.

Berdasarkan beberapa pendapat para ahli di atas,disimpulkan pengertian IPS adalah suatu disiplin ilmu sosial atau bidang kajian sosial kemasyarakatan yang mempelajari manusia pada konteks sosialnya atau manusia sebagai anggota masyarakat. Bidang kajian Ilmu sosial, studi sosial, dan IPS sama-sama mempelajari kehidupan manusia dan interaksinya dalam masyarakat.

Proses pembelajaran merupakan suatu hal yang dilakukan untuk menyampaikan suatu materi terhadap siswa dari sumber informasi, yaitu guru. Strategi pembelajaran ini menjadi langkah awal yang harus di ketahui sebelum guru melakukan proses belajar-mengajar pada siswa dalam kelas.

Gerlach dan Ely (1980) menjelaskan bahwa strategi pembelajaran merupakan cara-cara yang dipilih untuk menyampaikan metode pembelajaran dalam lingkungan pembelajaran tertentu. Selanjutnya dijabarkan oleh mereka bahwa strategi pembelajaran dimaksud meliputi sifat lingkup dan urutan kegiatan pembelajaran yang dapat memberikan pengalaman belajar peserta didik.

Banyak macam metode pembelajaran akan memudahkan para guru dalam menyampaikan suatu materi terhadap penerima materi. Seorang guru pasti akan menerapkan suatu strategi pembelajaran yang baik untuk menghasilkan suatu prestasi kepada siswanya. Dengan strategi yang tepat, guru akan lebih mudah mengajar dan siswa akan lebih mudah menerima materi dari sumber informasi tersebut.

Strategi dalam kegiatan pembelajaran dapat diartikan secara sempit dan secara luas. Dalam pengertian sempit, istilah strategi itu sama dengan pengertian metode, yaitu sama-sama merupakan cara untuk mencapai tujuan.

Pembelajaran inquiry adalah rangkaian kegiatan pembelajaran yang menekankan pada proses berpikir secara kritis dan analisis untuk mencari dan menemukan sendiri jawaban dari suatu masalah yang dilakukan melalui tanya jawab antara guru dan peserta didik. Strategi pembelajaran ini sering juga dinamakan strategi heuritik, yang berasa dari bahasa Yunani yaitu heuriskein, yang berarti "saya menemukan ".

Strategi pembelajaran inquiry merupakan bentuk dari pendekatan pembelajaran yang berorientasi kepada peserta didik ( student centered approach). Dikatakan demikian karena dalam strategi ini peserta didik memegang peran yang sangat dominan dalam proses pembelajaran.

\section{METODOLOGI}

Penelitian ini dilakukan di SDN 2 Mambulau, kecamatan Kapuas Hilir Kabupaten Kapuas dengan subjek penelitian peserta didik kelas IV. Alasan mengadakan penelitian di SDN 2 Mambulau karena di SD ini terdapat permasalahan pembelajaran yang perlu untuk diteliti salah satunya yaitu rendahnya hasil belajar Ilmu Pengetahuan Sosial (IPS) disekolah ini.

Metode yang digunakan dalam penelitian ini adalah Penelitian Tindakan Kelas (PTK). Menurut Kurt Lewin penelitian tindakan kelas adalah suatu rangkaian langkah yang terdiri dari empat tahap, yakni perencanaan, tindakan, pengamatan, dan refleksi. Sedangkan menurut Burns, 1999 penelitian tindakan 
merupakan penerapan penemuan fakta pada pemecahan masalah dalam situasi sosial dengan pandangan untuk meningkatkan kualitas tindakan yang dilakukan di dalamnya, yang melibatkan kolaborasi dan kerja sama para peneliti, praktisi, dan orang awam.

Subjek dalam penelitian ini adalah siswa kelas IV Sekolah Dasar di SDN 2 MAMBULAU, Kecamatan Kapuas Hilir semester 2 tahun ajaran 2014/2015 dengan jumlah siswa 7 orang yang terdiri dari 6 orang laki-laki dan 1 orang perempuan.

Menurut Suharsimi A. (2004) ada tiga kata yang membentuk pengertian PTK, yaitu penelitian, tindakan, dan kelas. Penelitian adalah kegiatan mencermati suatu objek dengan menggunakan aturan metodotogi tertentu untuk memperoleh data atau informasi yang bermanfaat dalam meningkatkan mutu suatu hal, serta menarik minat dan penting bagi peneliti. Tindakan adalah kegiatan yang sengaja dilakukan dengan tujuan tertentu. Sedangkan kelas adalah sekelompok siswa yang dalam waktu sama menerima pelajaran yang sama seperti guru. Dalam hal ini kelas bukan wujud ruangan tetapi diartikan sebagai sekelompok siswa yang sedang belajar. Dalam penelitian ini dilaksanakan menggunakan model Kemmis dan Mc Taggart, pelaksanaan penelitian ini mencakup 4 langkah dalam setiap siklusnya yaitu :

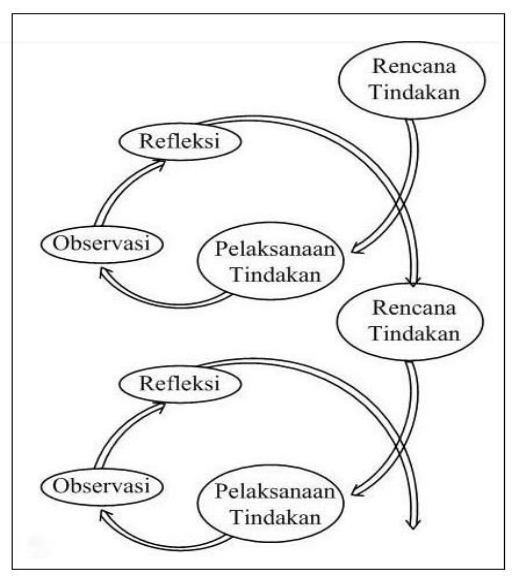

Gambar 1

Model Kemmis \& Taggart
Observasi bertujuan untuk mengamati kegiatan peserta didik dan guru selama penelitian pada kegiatan pembelajaran yang dilakukan oleh peneliti. Sudjana (2011:84) mengemukakan bahwa observasi atau pengamatan banyak digunakan untuk mengukur tingkah laku individu ataupun proses terjadinya suatu kegiatan yang dapat diamati baik dalam situasi yang sebenarnya maupun dalam situasi buatan. Sedangkan menurut Kusnandar (2008:73) " observasi dalam PTK adalah kegiatan pengumpulan data yang berupa proses perubahan kinerja SPI'. Berdasarkan pendapat para ahli di atas maka dapat disimpulkan bahwa observasi dalam penelitian ini digunakan untuk mengumpulkan data tentang keaktifan bertanya peserta didik dalam proses belajar mengajar.

Data yang dikumpulkan dari setiap kegiatan yang dilaksanakan dalam siklus PTK dianalisis secara deskriptif dengan mengguanakan teknik persentase untuk melihat kecenderungan yang terjadi dalam pembelajaran. Data yang diperoleh melalui instrumen yang telah dikumpulkan sebelumnya diolah menjadi dua jenis data yaitu kuantitatif dan kualitatif.

Data kuantitatif digunakan untuk mengetahui jumlah peningkatan hasil belajar yang terjadi pada peserta didik setelah pembelajaran berlangsung. Sedangkan data kualitatif adalah data untuk menerangkan tentang terjadinya pembelajaran. Sehingga pembelajaran dapat dirinci dan diterangkan melalui data kualitatif.

Penelitian ini merupakan penelitian dengan menghubungkan dua metode penelitian yaitu kuantitatif dan kualitatif. Sugiyono (2013:32) menyatakan bahwa:

Johnson dan Cristensen (2007) memberikan definisi tentang metode penelitian kombinasi (mixed recearch) sebagai berikut: Metode penelitian Kombinasi merupakan pendekatan dalam penelitian yang mengkombinasikan atau menghubungan antara metode penelitian kuantitatif dan kualitatif. Hal ini mencakup 
landasan filosofis. Penggunaan pendekatan kualitatif dan kuantitatif, dan kombinasikan kedua pendekatan dalam penelitian.

Metode penelitian kombinasi adalah suatu metode penelitian kuantitatif dan kualitatif untuk digunakan secara bersama-sama dalam suatu kegiatan penelitian. Sehingga diperoleh data yang lebih komprehensif, valid. Reliabel dan objektif. Dengan menggunakan metode kombinasi maka realibilitas data akan dapat ditingkatkan, karena relibilitas data yang tidak dapat diuji dengan metode kualitatif atau sebaliknya.

\section{HASIL DAN PEMBAHASAN}

Pra tindakan adalah perlakukan awal seorang guru kepada peserta didik sebelum memberikan atau memasuki materi pembelajaran. Dalam melakukan pra tindakan peneliti harus melakukan observasi pra tindakan dan tes pra tindakan yang dapat dijadikan sebagai tolak ukur keberhasilan pembelajaran selanjutnya.

Berdasarkan perhitungan nilai ratarata dan ketuntasan hasil belajar didapat hasil tes awal pada peserta didik kelas IV SDN 2 Mambulau didapat rata-rata sebesar 38,57 dengan ketuntasan belajar sebesar $57 \%$ yang termasuk kedalam kategori kurang tercapai. Nilai rata-rata peserta didik yang sebesar 38,57 masih belum mencapai kriteria ketuntasan minimal yaitu 60 dan nilai ketuntasan belajar sebesar $57 \%$ masih jauh dari kriteria ketuntasan secara klasikal yaitu $85 \%$. Sehingga pada tes awal tingkat ketercapaian keberhasilan pembelajaran masih belum memenuhi syarat ketuntasan belajar.

Refleksi dilakukan setelah seluruh kegiatan pembelajaran siklus I selesai, saat melakukan refleksi, peneliti dan dua orang pengamat berdiskusi membahas kegiatan pembelajaran yang telah dilakukan berdasarkan hasil observasi dan hasil belajar yang diperoleh peserta didik. Dalam pelaksanaan siklus I masih terdapat beberapa kekurangan baik pada peneliti ataupun pada peserta didik berdasarkan hasil pengamatan observer, ditunjukkan dengan ada beberapa poin penilaian yang hanya mendapat kategori cukup kurang baik. Pada hasil tes juga masih belum memenuhi nilai rata-rata ketuntasan minimal dengan nilai 62,85 dan juga belum memenuhi ketuntasan belajar secara klasikal dengan nilai sebesar $71 \%$.

Berdasarkan hasil observasi tersebut, pengamat memberikan saran agar peneliti memaksimalkan lagi pembelajaran dengan memperkuatkan pada bagian konfirmasi agar peserta didik lebih jelas memahami materi. Observer juga menyarankan agar membimbing peserta didik aktif dan berpartisipasi dengan tertib. Sehingga diharapkan tidak ada lagi kategori kurang.

\section{Tabel 1 \\ Rekapitulasi Hasil Belajar IPS \\ Pada Materi Koperasi Peserta \\ Didik Kelas IV SDN 2 Mambulau}

\begin{tabular}{|c|c|c|c|c|c|}
\hline \multirow[t]{2}{*}{ No } & \multirow[t]{2}{*}{ Nama } & \multicolumn{4}{|c|}{ Nilai } \\
\hline & & $\begin{array}{l}\text { Data } \\
\text { Awal }\end{array}$ & & iklus I & $\begin{array}{c}\text { Siklus } \\
\text { II }\end{array}$ \\
\hline 1 & $\mathrm{AE}$ & 20 & & 50 & 60 \\
\hline 2 & HD & 20 & & 60 & 70 \\
\hline 3 & FD & 65 & & 80 & 90 \\
\hline 4 & $\mathrm{JL}$ & 0 & & 25 & 55 \\
\hline 5 & MF & 75 & & 85 & 100 \\
\hline 6 & RZ & 60 & & 80 & 90 \\
\hline 7 & TQ & 30 & & 60 & 70 \\
\hline \multicolumn{2}{|c|}{ Jumlah } & \multicolumn{2}{|c|}{270} & 440 & 535 \\
\hline \multicolumn{2}{|c|}{ Rata - rata } & \multicolumn{2}{|c|}{38,57} & 62,85 & 76,42 \\
\hline \multicolumn{2}{|c|}{$\begin{array}{l}\text { Ketuntasan } \\
\text { belajar }\end{array}$} & \multicolumn{2}{|c|}{$57 \%$} & $71 \%$ & $85,7 \%$ \\
\hline
\end{tabular}




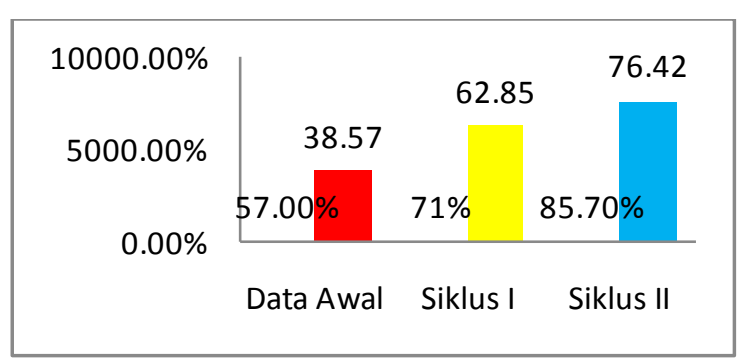

\section{Grafik 1. Hasil Belajar IPS Peserta didik Kelas IV}

Berdasarkan tabel di atas, dapat dilihat bahwa pada tes awal nilai rata-rata peserta didik hanya memperoleh nilai ratarata 38,57. Nilai ini masih jauh dari kriteria ketuntasan minimal yang ditentukan yaitu 60. Hasil ketuntasan belajar secara klasikal juga hanya memperoleh nilai sebesar 57\%, sedangkan kriteria ketuntasan klasikalnya minimal $85 \%$. Kemudian pada siklus I nilai ratarata peserta didik mengalami peningkatan sebesar 62,85 meskipun masih belum mencapai kriteria ketuntasan minimal, secara klasikal pun hanya masih belum mencapai $85 \%$, karena nilai yang diperoleh pada siklus I hanya sebesar $71 \%$. Pada siklus II nilai rata-rata peserta didik mengalami peningkatan cukup bagus dengan perolehan nilai rata-rata 76,42 dengan kriteria ketuntasan secara klasikal mencapai $85,7 \%$. Peneliti menganggap pada siklus II ini sudah berhasil karena telah mencapai nilai ketuntasan secara kalsikal. Namun pada hasil belajar peserta didik terdapat satu orang peserta didik yang tidak tuntas sejak tes awal hingga tes siklus II, hal ini menjadi kekurangan dalam penelitian ini.

Berdasarkan hasil penelitian diatas maka pelaksanaan perbaikan aktivitas, hasil belajar peserta didik pada materi koperasi dengan menggunakan strategi pembelajaran inquiry (SPI) dapat membantu meningkatkan keaktifan dan hasil belajar pada peserta didik kelas IV SDN 2 Mambulau. Semangat yang tinggi bagi peserta didik dan ketertarikan peserta didik terhadap belajar juga meningkat, maka pemahaman peserta didik terhadap belajar yang maksimal juga akan meningkat yang juga akan berimbas pada hasil belajar peserta didik. Indikator yang menunjukkan motivasi dan ketertarikan peserta didik dalam pembelajaran yang menjadi indikator penilaian pengamatan guru dalam penelitian ini adalah :

1. Keaktifan peserta didik dalam mengikuti pembelajaran indikator pencapaiannya adalah : peserta didik tidak sabar menunggu giliran menjawab pertanyaan yang diajukan peneliti dengan menggunakan Strategi pembelajaran Inkuiri.

2. Keceriaan, indikator pencapaiannya adalah : wajah gembira yang ditunjukkan peserta didik dan semangat yang tinggi.

3. Semangat belajar yang tinggi dapat dirasakan peserta didik dan mendapatkan percaya diri dalam menjawab soal maupun latihan dengan Strategi Pembelajaran Inkuri (SPI).

\section{KESIMPULAN}

Berdasarkan data hasil penelitian dan pembahasan dalam penelitian tindakan kelas (PTK) yang didapat peneliti selama penelitian dilakukan di SDN 2 Mambulau pada kelas IV adalah sebagai berikut :

1. Aktivitas peserta didik selama pembelajaran IPS dengan menggunakan strategi pembelajaran inquiry (SPI) lebih aktif. Hal tersebut sesuai dengan data observasi yakni, pada siklus I memperoleh skor ratarata 3 dengan kriteria baik, meningkat menjadi baik pada siklus II dengan skor rata-rata 3,6 dengan kriteria baik. Berdasarkan hasil tersebut dapat disimpulkan bahwa peserta didik merespon terhadap kegiatan pembelajaran yang dilakukan dengan menggunakan strategi pembelajaran inquiry (SPI).

2. Ada peningkatan hasil belajar IPS dengan menggunakan strategi pembelajaran inquiry (SPI) pada peserta didik kelas IV SDN 2 
Mambulau Tahun Pelajaran 2014/2015. Pada siklus I ada peningkatan hasil belajar peserta didik memperoleh data presentase $71 \%, 3$ orang peserta didik memperoleh nilai di atas KKM dari 7 orang jumlah peserta didik di kelas IV lalu 2 orang mendapat 60 sedangkan sisa 2 orang peserta didik masih memperoleh nilai<60. Dan ada peningkatan siklus II mengalami peningkatan dengan rata-rata skor presentase $85,7 \%$ dengan kriteria baik dari 7 orang peserta didik ada 5 orang yang mendapatkan nilai diatas KKM >60 sehingga siklus II dinyatakan tuntas dari klasikal yang diharapkan ditempat penelitian diatas $85 \%$.

Berdasarkan hasil penelitian yang dilakukan pada peserta didik kelas IV SDN 2 Mambulau bahwa dengan menggunakan strategi pembelajaran inquiry (SPI) dalam pembelajaran IPS materi Koperasi dapat meningkatkan hasil belajar IPS peserta didik maka disarankan :

1. Bagi kepala sekolah diharapkan dapat mendukung dan menyarankan guru-guru agar menggunakan dan manfaatkan media yang sudah ada dan guru-guru dapat menciptakan pembelajaran yang menyenangkan dalam rangka meningkatkan motivasi belajar peserta didik.

2. Bagi guru sebaiknya dalam proses pembelajaran IPS menggunakan strategi pembelajaran inquiry (SPI), agar peserta didik menjadi lebih fokus dan bersemangat juga termotivasi untuk belajar. Sebelum menerapkan pembelajaran dengan menggunakan Strategi pembelajaran inkuiri (SPI) guru harus menguasai materi pembelajaran yang sudah ada dipelajari maupun materi yang akan dipelajari sebagai data awal dan mampu mengaitkan materi pembelajaran dengan kehidupan yang nyata.
Bagi peserta didik, disarankan agar lebih aktif mampu berfikir secara kritis, logis dengan penerapan strategi pembelajaran inkuiri(SPI) pada pembelajaran IPS, serta lebih giat belajar agar mendapatkan hasil belajar yang baik.

\section{DAFTAR PUSTAKA}

Djamarah, (2011). Pengertian Belajar dan Hasil

Belajar.http://Duniabaca.com.html. Diakses tanggal 03 Maret 2012

Aqib, Zainal. (2014). Model-model, Media, dan Strategi Pembelajaran Konstekstual (Inovatif). Bandung : Penerbit Yrama Widya.

Hamalik, 2008. Proses Belajar Mengajar. Jakarta: Bumi Aksara.

Iskandar. (2008). Metodologi Penelitian dan Sosial (Kuantitatif dan Kualitatif), Jakarta : Gaung Persada Press.

Kunandar. (2012). Langkah Mudah Penelitian Tindakan Kelas Sebagai Pengembangan Profesi Guru. Jakarta: PT Raja Grafindo Persada.

Kuswantini. (2008). Penerapan Metode Inkuiri untuk Meningkatkan Hasil belajar Siswa Kelas IV SDN

Pusungmalang II Kabupaten Pasuruan. Pasuruan ; K uswantini.

Ngalimun. 2012. Strategi dan Model Pembelajaran. Banjarmasin :Aswaja Pressindo.

Nur Hamiyah \& Muhammad Jauhar. (2014). Strategi belajar mengajar dikelas. Jakarta : Prestasi

Pustakaraya.

Nasikhul, Muhammad. (2013). Makalah Metode Penelitian Kombinasi. (http://muhammadnasikhul.com/201 3/10/makalah-metode-penelitian- 
kombinasi). Diaskes bulan oktober 2013.

Rahmadani, Mawaddah,dkk. (2012). Penerapan Strategi Pembelajaran Inkuiri (SPI) Untuk Meningkatkan Hasil Belajar IPS Siswa Kelas IV Sekolah Dasar Negeri 153 Pekanbaru. Pekanbaru : Rahmadani.

Roestiyah. (2008). Strategi Belajar Mengajar. Jakarta. Rineka Cipta.

Sanjaya, Wina. (2006). Strategi Pembelajaran Berorientasi Standar Proses Pendidikan. Jakarta: Kencana.

Sari, Permata Berlian. ( 2013). Upaya Meningkatkan Hasil Belajar Matematika dengan Menggunakan Media Papan Berpaku.Palangkaraya :FKIP Universitas Muhammadiyah Palangkaraya.

Suhardjono. (2006). Penelitian Tindakan Kelas Sebagai Kegiatan Pengembangan Profesi Guru. Jakarta: Bumi Aksara.

Suharsimi, A., dkk. (2006). Penelitian Tindakan Kelas. Jakarta : Bumi Aksara.

Suharsimi Arikunto. (2006). Penelitian Tindakan Kelas, Jakarta: PT Bumi Aksara. Sukayati. (2008). Penelitian Tindakan Kelas di SD. Yogyakarta.

Susanto, Ahmad . (2013). Teori Belajar dan Pembelajaran di Sekolah Dasar. Kencana: PT Kharisma Putra Utama.

Tim skripsi FKIP Universitas Muhammadiyah Palangkaraya.

Yaba. (2006). Ilmu Pengetahuan Sosial 1.Program Studi PGSD Universitas Negeri Makassar : Makassar.
Yamin, Martinis. (2013). Strategi dan Metode dalam Model Pembelajaran. Jakarta : Referensi (GP Press Group).

Suprihatingrum, Jamil. 2014. Strategi Pembelajaran Teroti dan Aplikasinya. Jogjakarta: Ar-Ruzz Media

Trianto. 2013. Model Pembelajaran Terpadu. Jakarta: Bumi Aksara

Tim Penyusun (2013), Buku Pedoman Penulisan Skripsi, Palangkaraya UMP

Warsita, Bambang. 2008. Teknologi Pembelajaran dan Aplikasinya. Jakarta: Rineka Cipta 